Article

\title{
The City of Man, European Émigrés, and the Genesis of Postwar Conservative Thought
}

\section{Adi Gordon ${ }^{1}$ * and Udi Greenberg ${ }^{2}$}

1 Department of Judaic Studies, University of Cincinnati, Cincinnati, OH 45221-0169, USA

2 Department of History, Dartmouth College, Hanover, NH 03755, USA;

E-Mail: udi.greenberg@dartmouth.edu

* Author to whom correspondence should be addressed; E-Mail: adi.gordon@uc.edu.

Received: 5 June 2012; in revised form: 14 July 2012 / Accepted: 16 July 2012 /

Published: 6 August 2012

\begin{abstract}
This article explores the forgotten manifesto The City of Man: A Declaration on World Democracy, which was composed in 1940 by a group of prominent American and European anti-isolationist intellectuals, including Thomas Mann, Reinhold Niebuhr, and Hermann Broch. Written in response to the victories of Nazi Germany, the manifesto declared that the United States had a new global responsibility not only to lead the war against fascism and Marxism, but also to establish a global order of peace and democracy under U.S. hegemony. Moreover, the authors of the manifesto claimed that such an order would have to be based on the rejuvenation of conservative values; in their view, the collapse of Western democracies under the weight of totalitarian aggression was the consequence of inner moral and intellectual degeneration. The City of Man therefore called on the United States to lead the spiritual transformation of democracy into a modern political religion, which would bring about the intellectual and political unity of humanity under one state and one creed. This article analyzes the manifesto as a rare window into the difficulty intellectuals faced as they tried to conceptualize the totalitarian challenge prior to the United States' entry into the war. Moreover, it claims that The City of Man expressed the emergence of postwar conservatism and Cold War ideology, as well as the unique role played by European émigrés in this process.
\end{abstract}

Keywords: Americanism; European émigrés; anti-isolationism; totalitarianism; world federalism; conservatism; democratization; Judeo-Christian; Pax Americana; Cold War ideology 


\section{Introduction}

The heroic evacuation of Dunkirk, marking the imminent fall of France and with it the rest of Europe, began on Sunday, May 26, 1940. On that bleak weekend, in a gray and rainy Atlantic City, a group of anti-isolationist intellectuals gathered to compose a manifesto geared to guide the United States' path now that Europe's fate had been sealed. "The entire Old World," they wrote, "where our forefathers lie and whence all life and light came to us, sinks in a catastrophe unequaled in the record of man" [1]. The members of the group were alarmed that Americans had failed to grasp the full significance of Europe's demise, the true nature of the totalitarian threat, and the new responsibility that the war in Europe bestowed upon the United States. They believed that the country was mired in internal conflict and degenerate defeatism, which prevented it from realizing its duty to enter the war. The mood at the meeting was decidedly gloomy [2,3].

The declaration that ultimately emerged from this meeting, however, was as optimistic as it was ambitious. The authors assumed that the United States' entry into the war was both imminent and inevitable, for "[w]ar, declared or undeclared, actual or virtual, has chosen us" [4]. Moreover, the declaration went beyond other voices that supported U.S. intervention in the European war, adopting a radical proposal calling upon the United States to prepare for its inevitable goal of constructing a new post-war order. The United States, the writers claimed, had no choice but boldly to assume global leadership and create a universal state. Through its new found hegemony, it would establish a global order of peace, democracy, and prosperity. Part of the declaration, in fact, included a detailed program for the construction of this state's institutions. Yet the element that the writers considered most important was the drafting of a spiritual program, designed to guide the United States in this new global order. According to the authors, it was only by accepting the spiritual legacy of the collapsing Europe, "whence all life and light came," and, more specifically, by bringing about a religious revival, that the United States could hope to succeed in its mission. Invoking Augustine's The City of God, they called their manifesto The City of Man: A Declaration on World Democracy, and they themselves embraced the name "The Committee on Europe" or the "Committee of Fifteen." In the authors' minds, the manifesto was to serve as a practical blueprint for policymakers, and the Committee as their advisors.

If the manifesto's radical proposal was unique, the composition of the "Committee" was exceptional. The individuals who gathered in Atlantic City included both prominent intellectuals of the European migration and North American thinkers, a rare example of such cooperation in the period's intellectual landscape. Indeed, it was this diverse background that formed the basis for their ambitious goal of fusing "European" and "American" visions to produce a roadmap for a new global order. The driving force behind the Declaration's genesis was Giuseppe Antonio Borgese, the Italian literary critic and journalist. Under his energetic stewardship, the Committee was joined by Thomas Mann, the uncrowned leader of the German intellectuals in exile (and Borgese's father-in-law); the Austrian author Hermann Broch; the renowned scholar of nationalism Hans Kohn, who had only recently abandoned his Zionist and pacifist convictions and left Palestine for the United States in 1934; and the Hungarian ex-politician Oscar Jaszi, who since 1925 had worked as a scholar in the United States. From the United States, participants included the Christian theologian Reinhold Niebuhr; the Harvard political scientist William Yandell Elliott, at the time one of President Roosevelt's close advisors; the 
scholar of urban life Lewis Mumford; and several other journalists and scholars, such as Herbert Agar, Frank Aydelotte, and Dorothy Canfield Fisher.

The attitude adopted by the European émigrés in the group, who were both the initiators of the project and the more active members of the Committee, was peculiar. While most of them had only recently arrived in the United States, often with scant knowledge of their host society, they did not shy away from writing about America's destiny and values for Americans and as Americans. Rather than establishing their authority as "men of the world," as European cultural insiders, they preferred not to be identified as European exiles. Hans Kohn, who was born in Habsburg-era Prague, went so far as to state at this forum that "American political traditions and doctrines had been undermined by the largescale migration since the [eighteen] eighties from the politically most backward parts of Europe" [5,6]. This, of course, was a problematic case for a central European to make, especially as he purported to explain to Americans what their "American political traditions and doctrines" actually were. Indeed, unlike many renowned members of the German emigration, the European members of the Committee did not make disdainful statements about the reactionary elements in American life [7]. Hence, aware that their core group consisted of "prominent European personalities who have left their native countries and have carried across the ocean their knowledge and their ardor," the Committee strove to create in their group "a majority of American thinkers and scientists" [8].

While The City of Man has been all but forgotten by scholars, the story of its composition represents a crucial moment both in the history of European migration and in the evolution of Cold War thought. By analyzing the text's interpretation of contemporary world politics, its social-political proposals, its religious convictions, and finally its relationship to Augustine's The City of God, this short essay sheds light on two moments of intellectual transition. First, while scholarship on Central-European immigration in the United States has often focused on liberal and Left-leaning circles, the "Committee of Europe" tells the story of a deeply conservative tendency among certain exiles [9-15]. In fact, while some of the manifesto's authors, most notably Hans Kohn and Reinhold Niebuhr, were self-proclaimed liberals, The City of Man represented a conservative moment in their writing [16-18]. The text is replete with classic conservative statements: about the role of the family and private property as the pillars of civilization; the foundational role of Christianity in the establishment of legitimate political order; opposition to large-scale economic planning; and the corruption of traditional values in the era of mass consumption and industrialization [19]. Indeed, while most European conservative thought had been absorbed by 1940 by the authoritarian regimes that emerged in Europe, the manifesto was a rare attempt to reconstitute a conservative, pro-democratic, and firmly anti-Nazi position by redefining both the totalitarian crisis and the role of the United States in the world [20,21]. Studying the themes and evolution of the text thus sheds light on the process of adaptation on the part of conservative thinkers to the new conditions of emigration in the face of rapidly changing international conditions [22-27].

Second, and equally important, the manifesto reflects the transition from the international visions of the 1920s to the hard-headed ideology of the Cold War. On the one hand, The City of Man presents the seeds of Cold War thought; in it, the writers define the United States through its destined role as the vanquisher of totalitarianism and protector of world democracy. Like many early Cold War texts, it envisions that the United States' heroic fight against Fascism — which in 1940 was still in the realm of the authors' fantasy - would continue into the future and defeat other forms of totalitarianism, in 
particular Communism. Yet the manifesto's agenda was also marked by visions of peace, religion, and democracy that had evolved in earlier contexts and in other, European cultures. It reflected conservative and strong utopian impulses that had been formed years before the beginning of the war in Europe. The manifesto was therefore a unique attempt to adjust earlier convictions to new realities. This process, with its tensions and contradictions, generated a variety of programmatic ideas, some of which would be forgotten, while others would continue to resonate beyond the moment of 1938-1940.

\section{Defining the Enemy: Communism, Nazism, and the "Obsessive Myth of the Modern Mind in its Decay"}

While the European authors in the group that gathered in Atlantic City had been observing European politics with alarm for years, it was only in 1939 that they decided to call on the United States to intervene and reform the old continent. Shocked by the Munich Agreement of November 1938, in which the British and French Empires agreed to Hitler's demands and acquiesced in the dismembering of Czechoslovakia, Borgese began to contemplate a proposal for an alternative Western diplomacy. In May 1939 he composed the group's first memorandum, which outlined potential topics of discussion. After months of deliberations, Thomas Mann, Reinhold Niebuhr, and Lewis Mumford joined him in March 1940 in inviting the other members to participate in the official drafting of The City of Man.

The first mission that the group set itself in its manifesto was to define Europe's new regimes, and to explain why their growing power posed a threat not only to Europe, but also to the United States. Yet even though many of the Europeans in the group were refugees from right-wing regimesBorgese from Fascist Italy, Jaszi from militarist Hungary, Mann from Nazi Germany-one of the main drivers of their declaration was anti-Communism. To the members of the group Communism was a destructive force, a deadly ideology second only to Nazism, which could not co-exist with democracy. In fact, the group's first memorandum constituted not only a protest against the "appeasement" of Nazism in Munich, but also a warning against potential rapprochement between Western powers and the Soviet Union [28]. The memorandum stated that one of the major threats posed to democracy by fascism was that it might force Western countries into a dangerous anti-fascist alliance with the Soviet Union. "If the Western powers," Borgese warned, "perhaps fortified by a more or less ambiguous alliance with Russia, will resist the forthcoming challenges of Nazism and Fascism, a conflagration may ensue with consequences as huge in immediate loss of wealth and human lives as in the probable aftermath of chaotic revolutions" [29]. To these émigrés Communism posed a threat as grave as fascist domination. In this first memorandum, the Committee identified one of the areas on which it hoped to advise statesmen as "the deadlock of economic class warfare" [30].

While the Molotov-Ribbentrop Pact in August 1939 had rendered the authors' fears of a Western alliance with the Soviet Union irrelevant, it spurred them to combat Marxism with greater urgency. The diplomatic earthquake in Europe, in fact, merely intensified their anti-Soviet rhetoric and fear of Soviet expansion. The letter of invitation to the gathering in Atlantic City, for example, began by lamenting not only the fall of Poland, but also the fall of Finland to Soviet troops. It discussed "the conversion of Bolshevism... with Nazism... to aggressive expansion" and stressed that the foundations of Europe were plagued not only by "racial rancor," but also by "class-hatred" [31]. Weary of Soviet 
might, members of the Committee conflated all Marxist thought with Communism, asserting that the former inevitably led to the latter. Capitalist societies, they warned, had to address the revolutionary impulses so widespread among the working class, or else they would disintegrate from within [32].

Most of the manifesto's thrust, however, concerned the threat of Nazism. As much as it was a guide for a future world order, The City of Man was an attempt on the part of conservative European émigrés to provide a definition and analysis of the Nazi present. According to the manifesto, Nazism was the most radical form of nihilism. It was an explosion of brute force, a rejection of all moral codes and of civilization itself. "The barbarians of the early Middle Ages were eager to learn in the school of Christ and Rome," the authors warned. "But nothing is holy to their successors of our day, and the lawlessness of power is their only law" [33]. In the eyes of the Committee, Christians failed to recognize that Nazism was in essence an assault on their own beliefs, and that the two could not co-exist. They vehemently condemned Germany's Christians for supporting Hitler and "celebrating through seven days the triumphs of an Antichrist" [34].

According to The City of Man, Bolshevism and Nazism were twin manifestations of the same process: the response of uprooted masses to modernization, the temptations of modern technology, and weakening traditional ties. In the authors' eyes, the disintegration of such ties and the materialism of urban life left individuals stripped of their dignity and individuality. Under the pressures of modern economic competition, they became members of mass organizations, obedient participants in formless movements. In this analysis, the Communists and Nazis equally directed the masses' blind anger against civilization. In the manifesto's apocalyptic language, "the festering masses... generated volcanic forces, which shatter and rend when seeming accident gives them vent." In these conditions,

The despair of the masses needs only ruthless leadership to become the revolt of the masses. The leadership was provided in the Old World. The emptiness of man's heart was filled with the pride of the conquering hordes or with the slumber of the enslaved herd, and today['s] mass-man, rootless man, has been summoned to the destruction of civilization by which he had been betrayed [35].

To the frustrated masses who felt the meaning draining out of their life, the ruling classes promised a coming age of plenty, with rising standards of living. "Poverty and insecurity remained, but our mechanical prowess, with its millions of gadgets, was the answer to the ancient needs of man" [36]. In such a world, "[t]he sword will again be mightier than the pen, and in carnivals of destruction brute force and wild frenzy will alternate with the lethargy of a declining civilization" [37]. To the authors of the manifesto, Nazism was not merely a form of intense nationalism or imperialism. Rather, like Communism, it contained at its core a nihilist orgy of violence, bereft of values or meaning.

Borgese, Mann, Niebuhr, and the rest of the Committee furthermore agreed that the ideological structures of Marxism and Nazism were such that each could easily lead to the other. Indeed, Nazism inhered "the anarchy $[\ldots]$ of a degenerate socialism [...] which substituted for the idea of Justice the scheme of mass-regimentation, with its equality of servitude and its universality of deprivations" [38]. The Committee believed that Germans' acceptance and support of Nazi rule was "the outcome of bleak decades of training in the impotence of class-struggle and class-grudge." This was because both relied on "the fading of all faith and hope except the crude dogma of materialism and the desire for rising standards of living and steadier security." In essence, both the radical Left and radical Right were united in their worship of material comfort, and in utopian visions of prosperity. Pointing to what they 
saw as ideological similarities between Nazism and Communism, the drafters of the manifesto added that "Stalin, working through from the other end, inevitably reaches Hitler, in the middle of the same darkness" [39].

Moreover, The City of Man claimed that at a deeper level both ideologies were the most radical manifestations of the modern desire for revolution. According to the manifesto, the glorification of revolution was a malaise of modernity, the product of the modern impulse to abandon all traditional bonds and customs. By seeking to produce the classless society or the master race, the Communists and the Nazis ultimately joined hands in completing the process of modernization. "Revolution," the authors lamented, was:

an obsessive myth of the modern mind in its decay... the counterpart of war. It is war itself, with fire and steel, with fraud and terror; nor is there any comforting choice between perpetual revolution as projected by extreme Communism into the infinity of Evil and eternal war as hallowed by Fascism and Nazism in their black masses [40].

In the authors' eyes, Fascism and Communism merged into a single, perverse system, possessing the same spiritual source and, ultimately, developing the same political nature.

By conflating the enemy regimes of Nazism and Communism, the authors of the manifesto were among the first thinkers to discuss the new "theory of totalitarianism." Indeed, they used the "totalitarian" neologism extensively throughout the text. This line of thought, which asserted that both political theories were in fact mere variations on a single, dark manifestation of modernity, would famously emerge as one of the most important terminologies of the Cold War in the West. In 1940, however, such statements were still relatively new in the United States. While political theorists had begun to develop this theory in the 1930s, the works by figures such as Hannah Arendt, Friedrich Hayek and Carl J. Friedrich that would elaborate it most influentially would appear only several years hence [41-45]. The City of Man, therefore, marked one of the first attempts to chart for American audiences the treacherous terrain of global enemies. The manifesto portrayed Europe's revolutionary regimes as destroyers of civilization, and the impending clash with them as inevitable.

\section{3. "The Anarchy of laissez-faire Liberalism": Conservative Thought, Liberalism, and Democracy}

The City of Man's fierce attack of Marxism and Nazism, however, did not mean that its authors embraced the liberal democracies of their time. Quite the contrary, the manifesto included an almost equally aggressive attack on modern liberalism, blaming it for the disasters that had befallen Europe and the world. The charge at the heart of the declaration was that liberal Western democracies were, in fact, neither truly liberal, nor genuinely democratic. If democracy were to survive the aggression of totalitarianism, it had to be reimagined and redefined in a conservative key.

According to the manifesto's drafters, it was ultimately liberalism that was the source of contemporary catastrophes. In its glorification of individuality and economic prosperity, liberalism had given birth to the material emptiness of the modern age. The manifesto maintained that " $\mathrm{t}] \mathrm{he}$ brute force and wild frenzy" of Nazism are "the mongrel product of rugged individualism as carried to utmost efficiency in the anarchy of laissez-faire liberalism, in the exploitation of the masses by competitive capitalism, and of a degenerate Socialism" [46]. It was liberalism, rather than 
authoritarianism or imperialism that had generated the social and spiritual conditions that eventually led to democracy's demise. Comparing the Nazis to figures of American history, the Declaration maintained that:

The Führer and war-lords of our times, the conquering beasts of prey, emerged from the same ferments which had bred, at earlier stages of social decay... the robber baron of industry, the ruthless money-maker and the political boss exploiting his municipal satrapy—or, at all stages of history, the individual felon rising against and above the community..." [47]

From the Committee's perspective, liberalism's preoccupation with individual liberty and economic prosperity had led to human hubris. Rather than robust cooperation with fellow citizens, it had shattered traditional ties and taught nothing but selfishness. It was the liberal era that "had flung open the gates of the prisons" in which "today's tyrants... had been criminal offenders" [48]. Both socially and intellectually, liberalism was the condition for totalitarianism's nihilist revolution.

This decisively conservative view of liberalism - as the nihilist destroyer of tradition - meant that totalitarianism was not a distant threat posed by foreign countries. Rather, the conditions for its emergence were present in the fabric of every liberal country, including the United States. To the authors, the history of the "robber baron" indicated that even their host country could fall prey to the nihilist revolt. Indeed, they believed that French and British appeasement and U.S. isolationism presented the clearest indication of their inner spiritual collapse:

In the decline of Western civilization the collective purpose of democracy, with its commandments of discipline and loyalty, had given way to a corrupted liberalism, with its claim of unrestricted liberty for each one to think and act as he pleased. The all-embracing benignity of this perversion reserved some applause for the rugged individualist who proved strong and free enough to kill the freedom of his countrymen; and the principle of noninterference in the domestic policies and in the mutual quarrels of other nations covered under a banner of superstitious liberalism the contraband of approval and help to whatever foreign country had freely chosen to forfeit its own freedom or had freely managed to kill the freedom of its neighbor [49].

It was because of "corrupted" liberalism's similarity to totalitarianism that "[t]he arm of totalitarianism is long enough to reach into the anchorite's desert... No refuge would be spared" [50]. The City of Man, therefore, was an extreme attack not only on Europe's new regimes, but also on the principles of disintegrated liberalism. Resting on openly conservative convictions, the manifesto claimed that any break with the past was bound to degenerate into revolution.

According to the writers of The City of Man, therefore, the rebirth and triumph of Western society could only be achieved through a return to the traditional values of the past. The individual's life, they wrote, is "humble in the knowledge of its limits, under the all-human dogma of fallibility. It has meaning only by participation in the unlimited past... and no one man... or generation can embody the heritage and promise of Man" [51]. According to the manifesto, this meaningful past could survive only through traditional voluntary associations, which together constituted the "democratic brotherhood of sacrifice." These included the "primary groups of family, educational association, neighborhood, and church," all of which had to be "restored in new forms with new life" [52]. According to this communitarian vision of society, it was "[t]he pillars of family and property" that were to be regarded as "unshakable and holy" [53]. The survival of civilization thus depended on the 
rejection of individualism and materialism, and on the revival of communal bonds. Only by such a return to the past could totalitarianism be defeated.

In these assertions, The City of Man echoed the era's most famous conservative attack on Nazism, namely Hermann Rauschning's The Revolution of Nihilism: Warning to the West, which was published in German in 1938 and a year later in English. A former Nazi who abandoned the party and went into exile, first in Britain and later in the United States, Rauschning famously depicted Nazism as a movement of nihilists. Like the authors of the manifesto, he maintained that Nazism was a modern mass phenomenon, a revolt of the masses, which sought to destroy traditional values such as religion and community; and like the Committee, he compared the German regime to its arch-enemy, the Soviet Union [54,55].

Yet The City of Man also radically broke with the Europe's contemporary conservative thought by enthusiastically and unequivocally embracing democracy. Going beyond Rauschning's support of monarchism, its authors declared democracy to be the only legitimate political system, and the only manifestation of traditional values. In their eyes, the totalitarian potential at the heart of liberalism had one clear consequence: "the concepts of a vital democracy," they boldly claimed, "must be dissociated from the notion of a disintegrated liberalism, which is a precursor of tyranny and a prey to it" [56]. Democracy must therefore find a new spiritual foundation.

According to the Declaration, the precondition for such a rejuvenated democracy was dramatic economic and social reform that could reverse the destructive effects of modernization. Yet even though the group included one of the Roosevelt Administration's closest advisors, William Yandell Elliot, its vision for a new economic order was based not on modern schemes of the welfare state, but on a return to the economic theories of the nineteenth century. The authors invoked the works of the late nineteenth century theoretician Henry George, to whom they referred as "an American prophet," in particular his 1879 Progress and Poverty [57]. According to George, the solution to the ills of modern society was the transformation of the land into public property, and the abolition of all taxes and regulations. He envisioned the disappearance of private ownership of land, and that all wealth generated from nature's resources was to be equally distributed among men and women. At the same time, the state was to withdraw from all economic regulation of labor and capital, and would only protect the sacredness of private capital. In George's view, this model would bring prosperity and justice to all [58-60].

In establishing its blueprint on such socio-economic ideas, the City of Man sought to offer a conservative reversal of all modern politics and a redefinition of democracy's intellectual core. Rather than observing it as the realization of individual wills, "the conflicting concourse of uncontrolled individual impulses... a dispersive atomism," the manifesto's authors envisioned democracy as "a harmony subordinated to plan... a purposive organism" [61]. They believed that welfare should be administered through voluntary charity, organized by local communities, and not by the bureaucratic agencies of the state. Ultimately, they concurred with Henry George's claim, "[p]olitical economy and social science cannot teach any lessons that are not embraced in the simple truths that were taught to poor fishermen and Jewish peasants by One who 1,800 years ago was crucified" [62].

The City of Man's conservative attack on liberalism as the foundation of totalitarianism on the one hand, and its enthusiastic embrace of democracy on the other render it an important milestone in the transformation of European conservative thought. The manifesto was one of the first attempts to 
redefine democracy as the only system that could resist the corrupting force of modernization and nihilism. Such a view of democracy, not as the agent of modernization or a system at best to be passively tolerated, but as the defender of traditional structures and bonds, was rare among European conservatives; and it was only with the advent of the Cold War that these notions would reach the mainstream of the European Right [63-65]. Yet this view's enthusiastic democratic conviction rendered its conservatism invisible to many readers. Even the few scholars who commented on the manifesto regarded its support of democracy as a sign of liberalism, overlooking its openly conservative language [66]. Paradoxically, it was their conservative convictions that led the manifesto's authors to offer a dramatically new vision for the future.

\section{Christianity and Judaism in the New Spiritual Order}

According to the "Committee of Europe," the key to the emergence of a new and conservative democratic order, that would defeat totalitarianism and transcend liberalism, lay in a religious revival. Democracy, they hyperbolically claimed, "is the plentitude of heart-service to a highest religion embodying the essence of all higher religions. Democracy is nothing more and nothing less than humanism in theocracy and rational theocracy in universal humanism" [67]. According to the manifesto's writers, the power and appeal of fascism lay in its spiritual energy; it was a secular religion, which demanded fanatical devotion. In this interpretation, the defeat of France and the weakness of the West were the result of spiritual faintness, of the skepticism and faithlessness of the secular age. Democracy, therefore, could survive only if it too, like its adversaries, became a religion. "A constitutional reform of democracy," they decisively argued, "cannot be founded but on the spirit of a new religion" [68]. This democratic religion, they claimed, was universal in its essence, and worshiped the dignity of man and the rule of law. It could accommodate worshipers of different backgrounds and beliefs. It was, indeed, by virtue of its universal nature that it could achieve eternal peace and unite the people of the world under a single, global state.

Despite such lofty statements about the universal nature of the democratic religion, however, and its compatibility with a variety of religions, the manifesto could not conceal the central role that Christianity played in the eyes of its authors. In a highly orientalist fashion, they claimed that democracy was inherently tied to monotheism, and that the nations of the world would have to follow in the footsteps of the United States on the slow march to progress. The "cults of exotic origins," they wrote, failed to reach "the universality of the religion of the Spirit, to which all men are witnesses... none of them willfully and consciously conflicted with the basic tenets on which the world-religion of the Spirit is founded."

The Asiatic doctrines, to be sure, withered in a saintly inertia which made them unable - from Buddhism and earlier down to the present day - to participate decisively in struggle and progress... Tolstoyism itself, a cross of West and East, and Gandhism itself, a cross of East and West, have been unable to offset altogether the debilitating influence of Asia's passive worship and of the commandment of non-resistance to evil [69].

In the opinion of these American and European authors, the religions that lay beyond the borders of the United States harbored no potential for spiritual revival. 
It was therefore only Christianity, they claimed, that would allow democracy to achieve its global triumph. Only Christianity could serve as the basis for a self-assured culture that would overcome the fascist threat and establish global peace. "This universal religion," the authors claimed, "harbored in the best minds of our age," was the "common prayer of democracy militant which must be the hymn of democracy triumphant... Its substance matured out of whatever rose highest in man's speculations and hopes" [70]. In sharp contrast to their comments on "Eastern" cultures, however, the authors were confident that Christianity would readily be embraced by the people of the world. According to their tortured logic, the vast majority of the world's population already believed in its principles, even if it was not wholly aware of it. "Most of us," the manifesto quoted President Roosevelt, "believe in the spirit of the New Testament. The statement is true even for great numbers of people who are not, or never were, under the direct influence of the Scriptures. It is true even for most of those who reject all kinds of transcendent belief and cling, or think they cling, to rational knowledge and scientific experiment alone" [71]. Ultimately, the creation of a democratic society and a Christian society were identical projects in the minds of the manifesto's authors.

The Christian impulse of the manifesto revealed itself in its ambivalent and uneasy attitude toward Judaism and Jews. Including former Jewish nationalists such as Hans Kohn, and the Jewish converts to Christianity Hermann Broch and Oscar Jászi, the Committee regarded the place of the Jewish minority as central to its imagined postwar order. In the authors' mind, the centrality of anti-Semitism in Nazi ideology positioned the Jews as the litmus test for the spiritual health of a community. "The Jew among us," they wrote, "survivor of persecutions, warns us by his very presence that anti-Semitism is the entering wedge of racism, the dusk of hatred which preceeds the totalitarian night." Like the failure of U.S. society to abolish its own racial discrimination, they wrote, the persecution of the Jews "helps us by reminding us that our slow progress is a mere token of the justice we pledged - until all races rise to equality in maturity" [72].

The City of Man therefore preceded the wartime rhetoric that would emerge in the United States in the following years, underscoring a natural bond between the Christian and Jewish communities [73,74]. In the same manner in which American intellectuals would soon declare that the United States was a "Judeo-Christian" culture, so did the manifesto place Judaism on an equal footing with Christianity as the twin elements of the future "common faith" of universal religion [75]. "The prophetic spirit and heroic universalism of the Hebraic traditions," they asserted, "have been and are incessantly expressed in unorthodox and even secular forms of Jewish life. They have brought and bring a contribution of inestimable value to the spirit of democracy" [76].

These statements, however, could not hide the aversion that the writers felt toward most Jews. In their eyes, Judaism represented passivity, in sharp contrast to the active and creative nature of the Christian faith. Indeed, the "Hebraic traditions" were valuable only as long as they followed the principles of Christian universalism and denounced any sense of Jewish uniqueness. "[M] ost of the Synagogue," they warned, "tempted to this course no doubt by the stern problem of survival which faces the Jewish people in a hostile world, was overcome by sterility... and by the racial stubbornness which severed the orthodox Jew from Jesus, highest of Jewish prophets" [77]. The authors doubted whether Jews could overcome their race and nature and join the necessary spiritual revival. According to The City of Man, democracy, like Christianity, was based on certain elements of ancient Judaism, which had endured only in the furthest margins of the contemporary Jewish world. Ultimately, 
the authors believed, Jewish rejection of the universal teaching of Christ reflected Judaism's undemocratic core.

The participation of Jewish authors in the writing of such statements, composed in the darkest years of Nazi persecutions, is perplexing. While no record remains to document their thoughts, one might speculate that their embrace of Christianity in the manifesto was informed by strategic considerations. The pronounced anti-Semitism among some in the isolationist camp in the United States, such as Father Charles Coughlin, who vocally warned that international Jewry was plotting to drag the country into war against its own interests, might have encourage the marginalization of Nazi anti-Semitism as ancillary to its alleged attack on Christianity. Indeed, Jewish émigrés such as Kohn might have believed that framing the manifesto in an openly Christian spirit would be the most effective way to persuade their U.S. readership to embrace their anti-isolationist agenda.

Beyond any potential strategic choices, the manifesto's ambivalence toward the place of the Jews in the anti-totalitarian struggle reveals the uneasy and not always inclusive origins of "Judeo-Christianity." Like many Christian thinkers, Catholic and Protestant alike, who abhorred Nazi racism in the 1930s and 1940s, the authors of The City of Man regarded Nazi attacks on the Jews first and foremost as a manifestation of the Third Reich's anti-Christianity [78]. To them, constructing ties between Judaism and Christianity was not intended to reveal deep spiritual connections between the two religions. Rather, its purpose was to expose the Nazi obsession with Jews as a marginal factor that afforded a glimpse of its true essence, namely its totalitarian mission directed against the Christian churches. Indeed, the Committee members found no difficulty in reconciling their attacks on Nazi anti-Semitism with embracing biological terminology to accuse Jews of "racial stubbornness." In The City of Man, the religion of democracy remained Christian in essence, and it was only those who embraced the essential Christian creed who could be admitted to the future world democracy.

\section{Universal Peace in the Universal State}

The City of Man's political, economic, and religious values culminated in its most utopian and concrete recommendation: the realization of Immanuel Kant's vision of "perpetual peace" through the establishment of universal harmony under a single global state. Prefacing what would, for a brief moment, become a popular idea in the United States at the close of WWII, the writers of the manifesto laid the blame for the failure of earlier attempts at international cooperation at the door of the principle of national sovereignty [79,80]. As long as humans were divided in separate nation-states, they would inevitably experience a clash of interests and dominance. "Peace," they wrote,

could not be the outcome of subtle bargaining in the clearing houses of secret diplomacy backed by standing armies. It cannot rest upon coalitions and ententes, or upon half-hearted security pacts; it cannot be achieved through structures like the League of Nations, which presumed to dispense justice without exercising power, or through one-sided and lame leaderships like that of England's and France's rulers...[81]

The mere existence of nation states, the manifesto declared, was a sign of modern degeneration, the awful disaster of human life. It was the source of nihilism and a belief in the supremacy of brute force.

Universal peace, according to the manifesto, could only be founded "on the unity of man under one law and one government... the Universal State, and State of States [82]." Only such a state deserved 
the title "The City of Man," the true manifestation of peace and justice. The unity of man was the only response to the threat of totalitarianism. "[A]ll that survives of mankind must breathe in one breath and fight in one fight, since the whole earth has become one living-space or dying-space for all nations of men [83]." In the authors' minds, this universal state was to be modeled on a multilayered structure, on a combination of local and central power. Like the United States, it would have an elected President, but its different states were to enjoy substantial autonomy. "[T]he pluralistic system of the American Commonwealth," they wrote, "although prevented so far from reaching a complete expression... had shown... that the combination of local autonomy with unitary authority is feasible on a continental scale, and therefore ultimately on a world wide scale [84]."

According to The City of Man, this utopian vision had an obvious and clear leader - the United States. In a narrative that was soon to become one of the core elements of Cold War ideology, the authors proclaimed that it was the United States' natural and inevitable destiny to lead the world into a future of order and peace, eliminating the totalitarian threat along the way. "Nothing could be more shocking to America's humility and pride," the manifesto stated "than the necessity to take leadership among the nations." This leadership, however, was far removed from arrogance and imperialism, and would constitute a form of service to the entire globe. Leadership, they wrote, "implies some sort of imperium. But there is a difference between imperialism and imperium."

Chosen by the objective circumstances of history for a privilege which is a service, for a right which is a duty. This is, indeed, the substance of a chosen people: power in the frame of service. [...] "Rome did not spread upon the world; the world spread upon the Romans." This was the destiny of other nations and cultures, in ancient and in modern ages as well. This - to the largest extent of world-leadership for world-communion in the comradeship of man-is the destiny of America, as manifest as it was unwanted, since the English speaking nations were "left to fight alone," and all the world must sink unless we take the helm. [...] There are in the family of nations children who must grow up, sick who must be cured, maniacs who must be confined, criminals who must be apprehended, before maturity and redemption become the common lot [85].

With this statement, the City of Man reached its climax. Engaged in the fight for its own spiritual survival against totalitarianism, the United States was revealed also as the power responsible for the freedom of the entire world. It was the heir to all of civilization, its citizens the new "chosen people" of the Christian faith. And most importantly, it was to be a leading polity and a determined force. As the authors concluded, "The healing of the world requires a firm hand... American leadership is world-trusteeship; the Pax Americana a preamble to the Pax Humana [86]." With such statements, the manifesto reflected the final transformation in the thought of former pacifists such as Hans Kohn and Reinhold Niebuhr, who, in the face of Nazi aggression, abandoned their earlier convictions and embraced the use of force as part of America's responsibility.

The City of Man thus adapted older messianic visions of the United States to the new conditions of total war. Reproducing old visions of the United States as a unique guarantor of civilization and Christianity, the manifesto went further by portraying its global mission against totalitarianism as an integral part of its identity. The U.S. declaration of independence, the manifesto claimed, was "an Old Testament of Americanism," and its new global leadership was to be the "New Testament of Americanism," the realization and fulfillment of its spiritual essence [87]. Indeed, so the authors believed, the United States could not survive as an enlightening model or as merely one among many 
forms of life. Rather, its very existence depended on global dominance and the universal teaching of Christianity. While this fusion of religion and diplomacy would become common among U.S. intellectuals and political leaders within a few years, in 1940 it still lay in the future [88].

The City of Man, therefore, presented both a nebulous pre-figuration of Cold War ideology and at the same time developed ideas and themes that were dramatically alien to it. It defined the United States through its opposition to totalitarianism, but also considered its ultimate objective to be the abolition of all sovereignty, including its own; it called for religious pluralism, but defined the spiritual power of the U.S. as dependent on Christianity alone; and it presented a vision that was unminstakingly utopian, yet claimed it to be the only concrete and pragmatic program for the defeat of totalitarianism. These tensions rendered the City of Man a heterogeneous and incoherent document, and within a few months, with the United States' entry to the war, it was forgotten altogether.

\section{Conclusion: The City of God and the City of Man}

The City of Man never directly mentions St. Augustine or his De Civitate Dei (City of God), yet it parallels Augustine's text in more profound ways than the mere allusion in its title. Whereas Augustine reflects on the fall of Rome, the 1940 manifesto reflects on the fall of Europe. Augustine's work set out to prove that it was not Christianity that had brought about Rome's demise, while The City of Man sought to prove that it was not democracy that had led to Europe's collapse. Both pointed to Christianity as offering the solution to the political catastrophes of their era.

The City of Man, however, inverted the original meaning of the term "City of Man." In Augustine's book, "The City of Men" (in plural) is the earthly city, a domain of vice and sin, the city which is "ruled by its lust of rule," the new Babylon [89]. It is contrasted to "The City of God," "the eternal city," "Jerusalem." According to Augustine's theology of history, all human history comprises the struggle between these diametrically opposed cities. "Cain [...] belonged to the city of men; after him was born Abel, who belonged to the city of God." [90] "[T]hese two cities," Augustine explained, "were made by two loves: the earthly city by the love of self, unto the contempt of God, and the heavenly city by the love of God unto the contempt of self" [91]. In stark contrast, in the 1940 manifesto, "the city of man" stands for concrete political action in the world, a military mission against fascism, racism, and revolution, and the establishment of new global institutions. Unlike Augustine, the Committee of Europe envisioned a concrete formula for a new political order, a global yet worldly state.

By positioning the United States at the center of this anti-totalitarian and Christian mission, The City of Man reveals the birth of Cold War ideology from the crisis of appeasement. The alleged necessity of a Pax Americana, the identification of the United States with the legacy of Western civilization, the advocacy of a muscular American democratizing mission in the world, all articulate key elements of Cold War ideology. Given the course of U.S. history in the decades that followed, this part of the manifesto strikingly anticipates the intellectual terms of the global conflict.

Much of the manifesto, however, would sound alien and incomprehensible to readers of the Cold War era. The City of Man's sincere advocacy of a world federation, its nineteenth-century concepts of social and economic reform, and especially its understanding of Nazism would not become part of the 
global conflict's intellectual mainstream. Indeed, these ideas did not stand the test of time, and to the current day reader they often seem insufficiently mature and even inadequately thought out.

This mixed legacy is a product of the years in which the Committee operated. It came into being in late 1938; published its first memorandum in spring 1939; and convened and drafted its declaration in spring 1940. The original drive, in the wake of the Munich agreement, focused on the larger, historical significance of appeasement as a tragic embodiment of the worsening crisis of liberal Western democracies. The writers' attack was not a critique along Realpolitik lines, but a fundamental accusation: now that liberal Western democracies themselves appeared to have abandoned their commitment to the tenets of democracy and to the core values of Western civilization, no-one could or would combat the fascist tide in Europe. More importantly, however, the City of Man's conference in Atlantic City took place in May 1940, more than a year prior to Operation Barbarossa, and a year and a half before the United States' entry to WWII. These two events of the second half of 1941 not only changed the course of WWII, but dramatically shaped the manner in which European and American thinkers comprehended Nazism in the ensuing Cold War decades.

Seventy years after its composition, the manifesto has become "unreadable." Much of it was an attempt to respond to questions that were existential in 1940, yet have since lost their urgency. Most of all, the manifesto revealed its authors' deep anxiety that, with the rise of fascism, Nazism, and Communism in Europe, it was both democracy and conservative values and traditions that had been discredited beyond repair. Even though it committed itself to optimistic and messianic visions of the future, The City of Man was written from the abyss of despair, and on the assumption that Europe was irretrievably lost. Yet it was this anxiety that led the authors to invest their hopes in the United States, and to define it as the only shield against totalitarianism. It was this anxiety that added to earlier highly idealist visions of the United States a new messianic mission to heal the world of its modern illnesses. Thus did the numerous European émigrés on the "Committee of Fifteen," before many in their host country, capture the dawn of the new "American Century."

\section{Acknowledgements}

The authors wish to thank Avner Greenberg, Sven-Erik Rose, Nitzan Lebovic, and the anonymous reviewers for truly thoughtful and valuable comments.

\section{References and Notes}

1. Herbert Agar, Frank Aydelotte, and Giuseppe Antonio Borgese, et al. The City of Man: A Declaration on World Democracy. New York: Viking Press, 1940, 11-12.

2. This description of the meeting is based on the memoirs of Lewis Mumford and the diary of Thomas Mann: Lewis Mumford, My Work and Days: A Personal Chronicle. New York: Harcourt, 1979, 391-394.

3. Thomas Mann. Tagebücher 1940-1943. München: S. Fischer, 1977-1995, 81-83.

4. Agar et al. The City of Man. 14.

5. Mumford. My Works and Days. 392.

6. This argument resembles that which Allen Bloom would famously make some 50 years later in his The Closing of the American Mind. New York: Simon and Schuster, 1987. 
7. Some of the often-mentioned cases are Bertolt Brecht and the Frankfurt School. Ehrhard Bahr has recently both addressed their anti-Americanism, and challenged (or at least qualified) it. See: Ehrhard Bahr. Weimar on the Pacific: German Exile Culture in Los Angeles and the Crisis of Modernism. Berkeley: University of California Press, 2007, 83-93.

8. Agar, et al. The City of Man. 101, 103.

9. The scholarship on liberal and left-leaning émigrés is extensive. See, for example, Bahr. Weimar on the Pacific. Berkeley: University of California Press, 2008, and notes 10-15 below.

10. Uta Gerhardt. Denken der Demokratie: die Soziologie im atlantischen Transfer nach 1945. Stuttgart: Steiner, 2007.

11. David Kettler, and Gerhard Lauer, eds. Exile, Science, and Bildung: The Contested Legacies of German Émigré Intellectuals. New York: Palgrave Macmillan, 2005.

12. Edward Timms, and Jon Hughes, eds. Intellectual Migration and Cultural Transformation: Refugees from National Socialism in the English-Speaking World. Vienna and New York: Springer, 2003.

13. Lewis A. Coser. Refugee Scholars in America: Their Impact and their Experiences. New Haven: Yale University Press, 1986.

14. Martin Jay. Permanent Exiles: Essays on the Intellectual Migration from Germany to America. New York: Columbia University Press, 1986.

15. On the emerging scholarship on conservative thought among émigrés, see: Noah B. Strote. "Emigration and the Foundation of West Germany, 1933-1963." PhD Dissertation, University of California-Berkeley, 2011.

16. On Niebuhr and liberalism, see, Eyal J. Naveh. Reinhold Niebuhr and Non-Utopian Liberalism: Beyond Illusion and Despair. Brighton: Sussex Acad. Press, 2002.

17. On Kohn and Liberalism, see Ken Wolf. "Hans Kohn's Liberal Nationalism: The Historian As Prophet." Journal of the History of Ideas 37 (1976): 651-672.

18. Some members of the Committee, such as Borgese, have long been regarded by scholars as conservatives; see for example David Ward, Piero Gobetti's New World: Antifascism, Liberalism, Writing. Toronto: Toronto University Press, 2010, 139.

19. It is notoriously difficult to arrive at a strict and uncontroversial definition of "conservatism"; for the purpose of this essay, we have relied on the definition provided by Jerry Muller, which defines conservatism through a set of basic assumptions: the defense of existing institutions, customs, and habits; belief in the inherent imperfectability of human nature; resistance to dramatic social change; the utility of religion; and skepticism toward humanitarianism. See his "What is Conservative Social and Political Thought?" In Conservatism: An Anthology of Social and Political Thought from David Hume to the Present. Princeton: Princeton University Press, 1997, 3-31.

20. For a classic work on the cooperation (and consequent disillusionment) of conservative thinkers with fascism and Nazism, see Jerry Muller. The Other God that Failed: Hans Freyer and the Deradicalization of German Conservatism. Princeton: Princeton University Press, 1987.

21. For a preliminary discussion of conservative tendencies among the émigrés from Nazi Germany, see Jean-Michel Palmier. Weimar in Exile: The Antifascist Emigration in Europe and America. London: Verso, 2006, 568-570. 
22. Scholarship has begun to pay increasing attention to the conservative elements in the European emigration. See, for example, Malachi H. Hacohen. Karl Popper, the Formative Years, 19021945: Politics and Philosophy in Interwar Vienna. Cambridge, UK: Cambridge University Press, 2000, and notes 23-27 below.

23. Eugene R. Sheppard. Leo Strauss and the Politics of Exile: The Making of a Political Philosopher. Waltham, Mass: Brandeis University Press, 2006.

24. Noah Strote. Emigration and the Foundations of West Germany. $\mathrm{PhD}$ Thesis, University of California, 2011.

25. James Chappel. Slaying the Leviathan: Catholicism and the Rebirth of European Conservatism. PhD. Dissertation, Columbia University, 2012.

26. Adi Gordon. "The Ideological Convert and the Mythology of Coherence: The Contradictory Hans Kohn and his Multiple Metamorphoses.” Leo Baeck Institute Year Book LV (2010), 273-293.

27. Udi Greenberg. "The Limits of Dictatorship and the Origins of Democracy: the Political Theory of Carl J. Friedrich from Weimar to the Cold War." In The Weimar Moment: Liberalism, Political Theology, and Law, edited by Kaplan, Leonard V., and Rudy Koshar. Lanham, Md: Lexington Books, 2012, 443-464.

28. Agar, et al. The City of Man, 97.

29. Ibid., 97-98.

30. Ibid., 104.

31. Ibid., 109-110.

32. Ibid., 112.

33. Ibid., 12.

34. Ibid., 81 .

35. Ibid., 18.

36. Ibid., 17.

37. Ibid., 51.

38. Ibid.

39. Ibid.

40. Ibid., 67.

41. The first works on Totalitarianism appeared in the mid-1930s in Europe, but the term and the theories began to take hold in the United States only in the mid-1940s. On the evolution of the theory of Totalitarianism, see James Chappel. "The Catholic Origins of Totalitarianism Theory in Interwar Europe.” Modern Intellectual History 8:3 (November 2011): 561-590, and notes 42-45 below.

42. Anson Rabinbach. "Moment of Totalitarianism." History and Theory 45 (2006): 72-100.

43. Wolfgang Wippermann. Totalitarianismustheorien: die Entwicklung der Diskussion von den Anfängen bis heute. Darmstadt: Primus, 1997.

44. Abbott Gleason. Totalitarianism: The Inner History of the Cold War. New York: Oxford University Press, 1995.

45. William David Jones. The Lost Debate: German Socialist Intellectuals and Totalitarianism. Urbana: University of Illinois Press, 1999.

46. Agar, et al. The City of Man, 51. 
47. Ibid.

48. Ibid., 52.

49. Ibid., 30-31.

50. Ibid., 12.

51. Ibid., 48.

52. Ibid. Emphasis added.

53. Ibid., 80.

54. See Hermann Rauschning. The Revolution of Nihilism: Warning to the West. NewYork, Alliance Book Corporation, 1939.

55. Following the United States' entry into the war, Rauschning too adopted, in his way, the democratic slogan: Hermann Rauschning. The Redemption of Democracy, the Coming Atlantic Empire. New York: Alliance Book Corporation, 1941.

56. Agar, et al. The City of Man, 31.

57. Ibid., 52.

58. See Henry George. Progress and Poverty: an Inquiry into the Cause of Industrial Depressions, and of Increase of Want with Increase of Wealth. New York, D. Appleton and co., 1880.

59. It is likely that the authors relied on a shorter version of George's text, which was published in 1929 with an introduction by John Dewey. Significant Paragraphs from Henry George's Progress and Poverty. New York: Robert Schalkenbach Foundation, 1929.

60. After WWII, several European conservative thinkers cited George's ideas as having inspired the notion of a Christian economic order. See Chappel, Slaying the Leviathan, 340.

61. Agar, et al. The City of Man, 33.

62. Ibid., 48-49.

63. On Christian Democracy, see, for example, Wolfram Kaiser. Christian Democracy and the Origins of the European Union. New York: Cambridge University Press, 2007, and notes 64-65.

64. Michael Gehler, ed. Christian Democracy in Europe since 1945. New York: Routledge, 2004.

65. Noel D. Carry. The Path to Christian Democracy. Cambridge, Mass.: Harvard University Press, 1996.

66. See, for example, Paul Michael Lützeler. "Kitsch and Art: Broch's Essay 'Das Böse im Wertsystem der Kunst'.” In Hermann Broch, Visionary in Exile. Rochester: Camden House, 2003, 67-88.

67. Agar, et al. The City of Man, 33.

68. Ibid., 80.

69. Ibid., 39.

70. Ibid., 36.

71. Ibid., 35.

72. Ibid., 69.

73. On this development see Mark Silk. "Notes on the Judeo-Christian Tradition in America." American Quarterly 36, no. 1 (Spring 1984): 65-85, and note 74 below.

74. Deborah Dash Moore. GI Jews: How World War II Changed a Generation. Cambridge, Mass.: Harvard University Press, 2004.

75. Ibid., 38. 
76. Ibid., 39-40.

77 Ibid., 40, emphasis added.

78. On the emergence of anti-racist yet still anti-Jewish Catholic thought, see John Connelly. From Enemy to Brother: The Revolution in Catholic Teaching on the Jews 1933-1965. Cambridge, Mass.: Harvard University Press, 2012. Connelly attributes the beginning of the transformation in the Catholic Church from anti-Semitism to tolerance and cooperation to the works of converts (mostly from Judaism, but also from Protestantism) who fled Nazi Germany and later Europe during WWII.

79. On the movement for world government, which enjoyed considerable popularity between 1942 and 1947 in the U.S., see Lawrence S. Wittner. One World or None. Stanford: Stanford University Press, 1993, 44-45, and note 80 below.

80. Joseph Preston Baratta. "The International History of the World Federalist Movement." Peace and Change 14, no. 4 (1989): 372-403.

81. Ibid., 23.

82. Ibid., 23-24.

83. Ibid., 61.

84. Ibid., 25.

85. Ibid., 61.

86. Ibid.

87. Ibid., 58-59.

88. On the role of Christian thought and messianism in particular in Cold War U.S. thought and culture, see Jason W. Stevens. God Fearing and Free: A Spiritual History of America's Cold War. Cambridge, Mass.: Harvard University Press, 2010.

89. Augustine. The City of God, translated by Marcus Dods. New York: Random House Modern Library, 1950, Book 1, chapter 1.

90. Ibid., Book 15, chapter 1.

91. Ibid., Book 14, chapter 28.

(C) 2012 by the authors; licensee MDPI, Basel, Switzerland. This is an open access article distributed under the terms and conditions of the Creative Commons Attribution license (http://creativecommons.org/licenses/by/3.0/). 